\title{
DIGITAL MEDIA: FRIEND OR FOE? \\ PRESCHOOL TEACHERS' EXPERIENCES ON \\ LEARNING AND TEACHING ONLINE
}

Noile media: prieten sau dușman? Experiențele de predare-învățare online ale profesorilor din învățământul preșcolar

\section{Miruna Luana MIULESCU}

Journal of Pedagogy, 2020 (2), 203 - 221

https://doi.org/10.26755/RevPed/2020.2/203

The online version of this article can be found at: http://revped.ise.ro/en/2020/

\section{(ㅇ) $(\Theta \odot$}

This work is licensed under the Creative Commons Attribution-NonCommercial-ShareAlike 4.0 International License. 94042, USA.

Published by:

\section{Centrul Național de Politici și Evaluare în EducaȚie \\ UNITATEA DE CERCETARE ÎN EDUCAȚIE}

http://www.ise.ro/

https://rocnee.eu/

Further information about Revista de Pedagogie - Journal of Pedagogy can be found at:

Editorial Policy: http://revped.ise.ro/editorial-policy/

Author Guidelines: http://revped.ise.ro/en/author-guidelines/ 


\title{
DIGITAL MEDIA: FRIEND OR FOE? PRESCHOOL TEACHERS' EXPERIENCES ON LEARNING AND TEACHING ONLINE
}

\author{
National Center for Policy and Evaluation in Education, \\ Education Research Unit, \\ Bucharest, Romania \\ miruna.miulescu@gmail.com
}

Miruna Luana Miulescu*

\begin{abstract}
Teaching using a synchronous and an asynchronous online environment has become increasingly widespread across the education sector and now this process has been accelerated, temporarily or permanently, due to the Corona Virus (SARS$\mathrm{CoV}-2)$ pandemic. The mass closure of nurseries, kindergartens, schools, high schools and universities has prompted the rethinking of the teaching and learning processes. Educators were forced to shift to an online mode of teaching overnight even if they did not properly feel capable to do so. Our study seeks to explore the experiences on teaching and learning online encountered by preschool teachers during their work in the context of COVID-19 physical school closure and explore the meaning of such practices in shaping in-service kindergarten educators' perceptions of digital media and online delivery. The participants of the present study are kindergarten teachers $(n=21)$ with a minimum of three years and a maximum of 10 years of teaching experience. They work with the same age group (three- to sixyear-old children), from 9 public inner-city kindergartens. By making use of a phenomenological qualitative inquiry, data was collected through participating at semi-structured interviews via ZOOM videotelephony software program in June 2020. After the data was recorded and transcribed, three main themes were distinguished. The key findings indicate that all the teachers experienced challenging moments while delivering online, but they were also able to identify advantages in such a stressful context. The results of the study show the need of a modernized
\end{abstract}

* Researcher, PhD, National Center for Policy and Evaluation in Education (CNPEE), Education Research Unit, Bucharest, Romania. 
approach to pedagogies on educational technologies and media that is driven by research informed analysis.

Keywords: digital media, ICT, in-service kindergarten teachers, perceptions, young children.

\section{Rezumat}

Predarea utilizând un mediu online sincron şi asincron a devenit din ce în ce mai răspândită în domeniul educa iei şi acum acest proces a fost accelerat, temporar sau permanent, ca urmare a pandemiei cauzate de virusul Corona (SARS-CoV-2). Inchiderea în masă a creşelor, grădini elor, şcolilor, liceelor şi a universită ilor a determinat regândirea proceselor de predare şi învă are. Educatorii au fost obliga i să treacă la un mod online de predare peste noapte, chiar dacă nu s-au sim it capabili să o facă în mod corespunzător. Studiul nostru urmăreşte să exploreze experien ele de predare şi învă are online întâlnite de profesorii de învă ământ preşcolar în timpul activită ii lor în contextul închiderii fizice a şcolilor din cauza COVID-19 şi să exploreze semnifica ia unor astfel de practici în conturarea percep iilor educatorilor din grădini ă în func ie de media digitală şi predarea online. Participan ii la studiul de fa ă sunt profesori de grădini $\breve{a}(n=21)$ cu o experien ă de minimum 3 ani şi maximum 10 ani, care predau la aceeaşi grupă de vârstă (copii cu vârste între 3 şi 6 ani), de la 9 grădini e de stat din Bucureşti. In cadrul unei investiga ii calitative de tip fenomenologic, datele au fost colectate prin participarea la interviuri semi-structurate prin intermediul programului software de videotelefonie ZOOM în luna iunie 2020. După prelucrarea şi analiza datelor, s-au distins trei teme principale. Cele mai importante constatări indică faptul că to i profesorii au experimentat momente dificile $\hat{\imath}$ timp ce au predat în mediul online, dar au putut, de asemenea, să identifice avantajele într-un context atât de stresant. Rezultatele studiului arată necesitatea unei abordări modernizate a pedagogiilor privind tehnologiile şi mediile educa ionale, care să fie ghidate de analize bazate pe cercetare.

Cuvinte-cheie: copii mici, media digitală, percep ii, profesori pentru învă ământ prescolar, TIC. 


\section{Introduction}

With the ever diversifying digital landscape of 21 st century society, online delivery can be found across a wide range of disciplines and education levels. Used properly, digital media can offer notable advantages (Dubicka, Martin \& Firth, 2019). Evidence suggests that online education may enable new opportunities for students and their institutions in terms of accessibility for nontraditional students (Paulus et al., 2010), as well as for those who live in isolated areas (Robinia \& Anderson, 2010), encourage positive student engagement (Anderson, 2008; Herrington \& Herrington, 2006; Pederson \& Liu, 2003), offer a more student-centered environment (Barker, 2003; Saltmarsh \& Sutherland-Smith, 2010), and enhance students' technologyrelated abilities (Bonk, 2009).

Nevertheless, even though e-learning experiences have undergone rapid expansion in the last few years and ICT's role in children's lives has proven to be helpful in many ways, there is still a modest body of research reporting on teachers' preparedness to deliver online teaching (Bolliger \& Wasilik, 2009; Dell, Hobbs \& Miller, 2008; Downing \& Dyment, 2013; McQuiggan, 2007). Also, multiple concerns remain around the appropriateness of technology-mediated education for children, especially those in early childhood education (Dong \& Newman, 2016; Howard, Miles \& Ree-Davis, 2012; Leung, 2012).

Teaching using a synchronous and an asynchronous online environment has become increasingly widespread across the education sector and now this process has been accelerated, temporarily or permanently, due to the Corona Virus (SARS-CoV-2) pandemic (Bolisani et al., 2020; Dhawan, 2020; Di Pietro et al., 2020; König, Jäger-Biela \& Glutsch, 2020; Teräs et al., 2020). The mass closure of nurseries, kindergartens, schools, high schools and universities has prompted the rethinking of the teaching and learning processes. Therefore, in order to find solutions to deal with the challenging situation, educators were forced to shift to an online mode of teaching overnight. However, even if the adoption of distance learning is crucial to ensure the continuity of education following the cancelled in-person instruction, this context does not automatically transform educators into professionals who have the technological and pedagogical competences required to teach 
online. Therefore, they are left with no choice other than to teach online even if they do not feel properly capable to do so (Buabeng-Andoh, 2012; Guerriero, 2017; Lewis \& Wang, 2015; McFarlane, 2019; McMurtrie, 2020). Moreover, digitally mediated education has become a widespread matter of concern not only for educational professionals, but also for parents. Transitioning from face-to-face or face-to-screen teaching and learning has been perceived as complex and problematic for all parties involved, all the more so for parents with preschool children.

Against this background, the present paper addresses the experiences on teaching and learning online encountered by kindergarten teachers during their work in the context of COVID-19 physical school closure, and thus might contribute to the further understanding of the changes brought by the digital learning environment for both children and educational institutions.

\section{Literature review}

The integration of digital media in education has led to a growing debate in relation to its contribution to the children's development, especially in the case of those in early education. Discussion around the pedagogical practices in the technology-mediated environment reveal a diversity of perspectives in relation to the positive or negative contribution to the pre-primary educational process.

A growing body of research covers the advantages of using information and communication technologies (ICT) in pre-school education. The utilization of digital media has been found to encourage significant interactions among children, leading to enhancement to their conversational skills (Hsin, Li \& Tsai, 2014). Technology in the kindergarten is perceived as positively influencing early cognitive development as it impacts the quality of children's play and their learning by cultivating their collaboration skills, curiosity and creativity. Furthermore, the new technologies considerably influence young children's literacy development, controlling and planning skills, as well as their mathematical thinking and problem solving abilities (UNESCO, 2010). In line with these findings, Magen-Nagar, Firstater and Schwasbky (2013) assert that the integration of ICT in small children's education leads to 
improvement in many areas, such as the cognitive functions (visual, analogical, abstract, and mathematical-logical), literacy, memory, metacognition, and motor-visual coordination.

Moreover, the integration of ICT into the classroom is of great interest to policy-makers (Keengwe \& Onchwari, 2009) and has been perceived as valuable for making the educational process more efficient (Nikolopoulou \& Gialamas, 2015; Saude et al., 2005). For this reason, many governments have begun to encourage the use of ICT with young children to sustain their development (Bakia et al., 2011). Equipping kindergarten-aged children with the knowledge and skills needed in the twenty-first century has been a priority for many states in the last decade (Yelland et al., 2008), as the USA (NAEYC, 1996), New Zeeland (Ministry of Education, 2005) or Scotland (Learning and Teaching Scotland, 2003) have made considerable progress in implementing curriculum guidance or frameworks for early childhood teachers with the focus on integrating ICT into the classrooms.

There are significant challenges, however, which are not left unnoticed by both practitioners and researchers. Magen-Nagar and Firstater (2019) note that research on digital media has yet to show any direct correlation between the use of ICT and achievements of children, regardless of their age. The researchers also notice that the extensive use of ICT can limit young children's emotional, physical and cognitive development in the longer run. There are also concerns over the interference of ICT with free play and the stimulation of individual activities to the detriment of social interactions (Cordes \& Miller, 2000). Opponents also claim that the communication process is not adequately enhanced in the case of kindergarten-aged children (Hsu, 2016). Furthermore, children are stopped from directly exploring the world using their active, sensory, and exploratory learning nature. With the purpose of seeking the perspective of educators, various studies revealed a common concern among teachers regarding their lack of technical skills necessary for using ICT effectively when teaching online (Mills et al., 2009; Wilson, 2004; Wray et al., 2008).

Teachers in Romania have been carrying out educational activities using digital tools and resources to some degree, so this situation should not constitute a novelty for most of them. Furthermore, in the last few years, the 
Ministry of Education and Research and its subordinate institutions promoted several initiatives and programs with a digital component (e.g., Computerized Education System (SEI) program, eTwinning action, various teacher training programs for developing technology-related competences, ROSE and CRED projects) (Botnariuc et al., 2020).

However, there is no specific national ICT policy for the early childhood education system and ICT professional development for kindergarten teachers is hardly mentioned. In this regard and in line with the educational change in 2020, the Ministry of Education and Research in Romania launched the public consultation process on the Education Digitization Strategy (SMART-Edu) and proposed a call for action for closer cooperation of all stakeholders for the development of digital skills at all levels of education, various Open Educational Resources (OER), and digital educational tools, the improvement of digital infrastructure, the support of pre-service and inservice digital training of teachers, the promoting of initiatives on online security, data protection, cyber hygiene, IT ethics, etc. (MEC, 2020).

In August 2020, the Ministry of Education and Research, through the National Center for Policy and Evaluation in Education - The Research Unit in Education (CNPEE, 2020), conducted a research addressed to students, teachers, school principals and parents, regarding the evaluation of the educational process which was exclusively mediated by technology, during the suspension of face-to-face courses. The aim was to identify the perceptions and opinions of the educational actors, regarding access to the teaching and learning process, the rate of participation at distance learning activities, additional support needs and priority areas for intervention by central and local authorities. Data was collected through 4 distinct online questionnaires addressed to the above-mentioned categories of respondents and more than 600.000 individuals from all around Romania completed the surveys.

The results show that the family plays an important role in supporting children to actively participate in learning online and their help was much appreciated by the school, given the fact that kindergarten-aged children are not completely autonomous in the use of educational applications. According to the information provided by the principals, the use of electronic means and 
new technologies has been dominant in organizing the learning activities. Nevertheless, there were also institutions that resorted to alternative forms of distance learning (i.e., non-digital), but only in the case of weak Internet connectivity or difficult access to ICT resources (CNPEE, 2020).

\section{Methodology}

As we already mentioned, this study's main objectives are to explore the experiences on teaching and learning online encountered by preschool teachers during their work in the context of COVID-19 physical school closure, and explore the meaning of such practices in shaping in-service kindergarten teachers' perceptions of digital media and online teaching and learning. To achieve this aim, the study is designed as a phenomenological qualitative inquiry. This design was carefully considered for the reason that the spotlight is on thoroughly understanding the subjects' experiences on a particular phenomenon. The specific phenomenon under study is investigated through collecting data (qualitative methods) and discovering commonalities between the participants' perceptions (Marshall \& Rossman, 2011). Accordingly, the phenomenological design supports the real-life experiences of in-service kindergarten teachers from public kindergartens in the Romanian educational system, during the COVID-19 in-person instruction closure.

\subsection{Research participants}

In the current study, the participants were selected based on availability (Teddlie \& Yu, 2007). The selection of participants was based on certain criteria, such as: professional experience of a minimum of three years and a maximum of 10 years of teaching experience, teaching the same age group (three- to six-year-old children), completed Bachelor degree studies in PreSchool and Primary Educational Pedagogy, as well as availability and eagerness to participate.

The participants of this study are kindergarten teachers $(n=21)$ meeting the above written criteria, alumna of the Pre-School and Primary Educational Pedagogy programme in the Faculty of Psychology and Educational Sciences, 
part of the University of Bucharest in Romania. They are aged 22 to 32, and work in similar contexts (9 inner-city kindergartens).

The first phase of the sampling process consisted of contacting the 37 teachers via e-mail and explaining them their prospective involvement in the research process. 21 of them agreed to be part of the investigation. Table no. 1 provides an overview of the participants' background information.

Table no. 1. Background information of the participants

\begin{tabular}{ll}
$\begin{array}{l}\text { Background } \\
\text { information }\end{array}$ & \multicolumn{1}{c}{ Participants } \\
\hline \hline Gender & All female \\
Stage of studies & $\begin{array}{l}\text { Bachelor's Degree in Pedagogy of Primary and } \\
\text { Preschool Education (n=15) and Master's } \\
\text { Degree in Educational Sciences (n=6) }\end{array}$ \\
& $\begin{array}{l}\text { As part of the curricula for teacher training } \\
\text { for pre-school and primary education, the } \\
\text { participants were required to complete } \\
\text { introductory courses to acquire fundamental } \\
\text { computer skills (Information and } \\
\text { Communication Technology - ICT, and } \\
\text { Computer Assisted Instruction - CAI) }\end{array}$
\end{tabular}

Personal ICT use All participants own a personal laptop and smartphone. All of them have been using social media for more than 5 years.
Notes

Representative as almost all inservice preschool teachers in Romania are female.

Representative as a great majority begin their initial training immediately after high school.

Information-rich cases as they had completed their compulsory practicum period.

Representative as all participants have basic computer knowledge and skills such as using Word, Excel or PowerPoint, accessing the Internet etc., as well as elementary knowledge and skills in utilizing specialized software in the educational field.

Representative as $72.4 \%$ of Romanian households had access to the internet from home, according to the Institute of National Statistics (2018). Also, mobile phones are the most used devices for accessing the internet among pupils. 


\subsection{Data Collection}

The data collection involved semi-structured interviews which were conducted with each educational professional via ZOOM videotelephony software program in June 2020. The length of the interviews ranged from 45 to 75 minutes, and the kindergarten teachers agreed to be audiotaped for a transcription and a better analysis of their responses. The interview questions focused on the research topic without revealing any privacy information or exploring any sensitive topics. The interview items were the following:

(1) If you could make a list of the top three most stressful or challenging experiences that you encountered in these last four months, what would this list include?

(2) What are the top three positive aspects of the online teaching and learning period? Please describe in detail why you considered them beneficial to you, your children etc.

(3) Did you receive support from the national or local authorities for better organizing your work? What about support from children's families or from your own colleagues? What kind of support did you receive? Was it helpful or not?

(4) Do you feel you have learned something from this experience? Please elaborate on your answer.

\subsection{Data analysis}

The interview data were analysed through qualitative content analysis (Bernard \& Ryan, 2010) for a better exploration of the acquired information. The data which was mainly descriptive was transcribed verbatim and then analysed. Based on the interview questions and the responses of the participants, the process consisted first and foremost of coding the meaningful broad categories so that the codes could be divided into different categories. Through a cyclical process we were able to list three main themes in the end: (1) teachers' challenging experiences during online teaching and learning, (2) teachers' perceptions of digital media benefits and potential, (3) support for online teaching. 


\section{Findings}

4.1. Teachers' challenging experiences during online teaching and learning

In our study, data shows that all the teachers experienced challenging moments while delivering online. The content analysis revealed four main obstacles which made it difficult for teachers to utilize the online environment to its fullest during the physical school closure (March - June 2020): the lack of confidence and competence in the pedagogical and technological skills; the integration of digital media (didactic obstacle); maintaining children engagement; poor technological infrastructure.

According to professionals' answers, all of them had trouble feeling at ease while teaching online due to the fact that they did not believe they had the suitable knowledge and skills to properly conduct an educational process for small children in a technology-mediated environment. Educational institutions in Romania, especially public ones, are currently based on traditional methods of teaching and learning, and they follow the traditional set up of face-toface activities in a classroom. Therefore, even if teachers had prior knowledge of how to deliver an online class, they did not have the occasion to exercise the needed skills in a real setting and on a daily basis. Therefore, we reckon that their fears are justified, as one of the teachers pointed out:

"I know how to access the Internet, to write a Word document or to create a PowerPoint presentation, but it is a whole different world to be able to create content for small children only with basic knowledge. [...] Also, I really don't want to remember the first few times when I had to get the hang of how to create meetings or to set again the internet connection because of a power failure in my neighborhood. [...] I definitely was not prepared for this..." (Teacher of three- to four-year-old children).

The introduction to the poly-synchronous world of teaching and learning was difficult not only for children, as the study participants stated, but also for the professionals. The rapid transition to online teaching found the teachers poorly equipped with pedagogical knowledge on how to integrate digital media into small children's activities and, moreover, how to properly translate faceto-face activities and content to the online-mediated environment. Only a 
handful of these educational professionals had ever done blended learning before and none had taught their class entirely online, even as student-teachers in their practicum period.

Therefore, the task was not a simple one: they were being asked to transition, develop, and implement online teaching (Rennie \& Morrison, 2013). Successfully integrating digital media intro teaching and learning, especially in an exclusively virtually mediated context is a more complicated phenomenon than the mere use of technological devices, aspect which was also highlighted by the educators:

"It was really hard for me to suddenly integrate ICT into my teaching. You can do it in a short time, of course, but only at surface level, because if you want to do it properly so that it has a positive impact on the child and it aims to develop certain aspects, then you should really be concentrated on that. But I, and I think I can speak for all educators, did not have the time to do so or learn how to do so. Everything was fast-forward style!" (Teacher of three- to four-yearold children).

Being able to maintain children's engagement through online activities was also a stress-provoking situation for teachers. Many of them observed that after the first two months, children began to refuse to participate actively to the synchronous classes and even more so to the asynchronous ones. A few teachers even mentioned that some children became isolated and refused to participate in any activity related to kindergarten, because they missed their colleagues and the interactions. One of the teachers confessed that:

"As we, me and the children, became accustomed to the online environment, I unconsciously began to focus more on demonstrating on the screen various aspects, because next year they will go to primary school and they need to be prepared, and less on building activities with a focus on interaction with peers. And the children sensed that it was not about them, but because I had to follow a schedule." (Teacher of five- to six-year-olds).

Also, in line with the above-mentioned struggle, one of the participants confessed that:

"Of course it is a good thing that technology is now used even in 
early childhood education because online services have become a big part of our everyday life, but I still think we should not dedicate too much of our time to such digital media." (Teacher of four- to fiveyear-old children).

Another area of dissatisfaction involved the poor technological infrastructure. For instance, teachers confessed that most families had difficulties in ensuring children's access to digital equipment which was adequate for educational activities. Many households had more than one child and in the case that also one or both parents had to work from home, the small child drew the short straw. There were many instances, as reported by the participants, where the child had to share the digital device or was not able to participate regularly to online activities. Also, several problems arose from both sides (teachers and children) because of the poor Internet connection.

\subsection{Teachers' perceptions of digital media benefits and potential}

In comparison to the difficulties posed by teaching in an online context, the teachers found it harder to explain the benefits of using digital media when conducting an educational activity. They recognized the advantages of ICT in a limited way, focusing mostly on the children's joy when interacting with ICT, at least in the first two months.

With changed spatial and temporal relations, educators had to make the most of what they had. As a consequence of the fact that the children admitted to missing the face-to-face contact with other colleagues, the teachers began to look for fun and active games, which brought great involvement from the little ones.

The digitally mediated environment offered flexible learning opportunities for all children, because now, as some teachers stated, the professionals had more time to adapt each activity to each child's strengths:

"I admit that in the first month or so I was not able to see any advantage to his situation, but slowly but surely I could see that I had more time to give to each child. I could set up a meeting with each child and parent and that time was entirely his/hers, with no 
disruptions, which cannot happen when you have a class of 25 kids around you." (Teacher of five- to six-year-old children).

Another common trait of this period seemed to be the growing relationship between the teacher and the parent. As the health and social situation was getting worse, there was a better understanding of the struggles the two parties face:

"These months have showed me that parents are important allies in a child's development and educational process. All I can say is that I feel more connected to my children's parents and we help each other a lot these days for the benefit of the small one." (Teacher of three- to four-year-old children).

\subsection{Support for online teaching}

In terms of support, the most significant initiatives have come from families, colleagues, town halls, local councils, and some NGOs, through facilitating the use of new technologies in educational contexts through platforms, applications, tools made available on dedicated sites, but also online seminars (webinars).

Help from other kindergarten educators was particularly noticed in the participants' responses. Even in the case of teachers that formerly had little interest in online teaching, they struggled to adopt strategies specific to the online environment in order to overcome the obstacles encountered by them and their other colleague educators; and in this way, small communities of teachers were fast created, with the purpose of easing each other's professional experiences.

\section{Discussion and conclusions}

According to Anderson (2020), the coronavirus crisis has led to "the world's biggest educational technology (edtech) experiment in history. With 1.5 billion students out of school and hundreds of millions attempting to learn solely online, the experiment will reshape schools, the idea of education, and what 
learning looks like in the 21 st century”.

In the present study we attempt to understand what it was like for teachers to deliver online classes to kindergarten-aged children during a crisis context necessitating rapid adaptations of materials and activities. Three topics were explored: teachers' challenging experiences during online teaching and learning, teachers' perceptions of digital media benefits and potential, and the support received by educators.

The data indicates teachers' limited understanding regarding the way digital media can be integrated properly into kindergarten activities, due to the fact that they did not previously acquire proper knowledge and skills in this respect. Had their training offered more opportunities for blended or online teaching and learning they would not have experienced so many challenging moments. There is no simple mapping of offline onto online. The use of digital media with kindergarten-aged children is different from its use in higher grades, due to the children's poor reading and writing abilities, and the learning methods are mainly founded on visual representations and auditory means. Also, the new technology-related context constraints children's direct tactile and hands-on experiences.

A common concern expressed by the educators was over the negative effects of prolonged media usage by small children, but, at the same time, they confessed that if they had prior competences for integrating digital media into teaching online, the after-thoughts would have been completely different and on a more positive note.

Nevertheless, professionals also pointed to some benefits associated with this mode of teaching and learning, mainly related to the curious nature of children for the new mean of transmitting knowledge and the support received from the families' side.

The technological landscape is now more diverse than ever. Even so, regardless of the help given by touch-screen technologies and educational applications, which have surely empowered the use of digital media in the educational process, many aspects of online education have remained unexplored. 
The practices during the pandemic which characterized the education in 2020 call for a modernized approach to pedagogies on educational technologies and media that is driven by research informed analysis. Furthermore, we support research endeavors that not only take the current pandemic as their priority of analysis, but proceed in improving our understanding of the complex relationship between technology and education, as well as in exploring new approaches to staff development.

All in all, one thing is for sure: the future appears more uncertain than ever, but perhaps now is the perfect time to make more firm and significant educational and digital changes.

\section{References}

- Anderson, T. (2008). The theory and practice of online learning (2nd ed.). Athabasca University Press.

- Anderson, J. (2020, March 30). The coronavirus pandemic is reshaping education. Quartz.

https://qz.com/1826369/how-coronavirus-is-changing-education/

- Bakia, M., Murphy, R., Anderson, K., \& Trinidad, G. (2011). International experiences with technology in education: Final report. Department of Education, Office of Educational Technology.

- Barker, A. (2003). Faculty development for online teaching: Educational and technological issues. The Journal of Continuing Education in Nursing, 34(6), 273-278.

- Bernard, H. R., \& Ryan, G. W. (2010). Analyzing qualitative data: Systematic approaches. Sage.

- Bolisani, E., Fedeli, M., Bierema, L., \& De Marchi, V. (2020). United we adapt: communities of practice to face the CoronaVirus crisis in higher education. Knowledge Management Research \& Practice, 1-6. https://doi.org/10.1080/14778238.2020.1851615

- Bolliger, D., \& Wasilik, O. (2009). Factors influencing faculty satisfaction with online teaching and learning in higher education. Distance Education, 30(1), 103-116. https://doi.org/10.1080/01587910902845949

- Bonk, C.J. (2009). The world is open: How web technology is revolutionizing education. Jossey-Bass.

- Botnariuc, P., Cucoş, C., Glava, C., Iancu, D.E., Ilie, M.D., Istrate, O., Labăr, A.V., Pânişoară, I.-O., Ştefănescu, D., \& Velea, S. (2020). Şcoala online: elemente 
pentru inovarea educa iei. Raport de cercetare evaluativă. Editura Universită ii din Bucureşti.

https://unibuc.ro/wp-content/uploads/2020/05/Scoala_Online_Raport_ aprilie_2020.pdf

- Buabeng-Andoh, C. (2012). Factors Influencing Teachers' Adoption and Integration of Information and Communication Technology into Teaching: A Review of the Literature. International Journal of Education and Development Using ICT, 8(1), 79-105. https://doi.org/10.1080/09523987.2018.1439712

- Centrul Na ional de Politici şi Evaluare în Educa ie. (2020). Invă area la distan ă. Anchetă cu privire la activită ile educa ionale desfăşurate în România, în perioada suspendării cursurilor şcolare fa $\breve{a}$ în fa $\breve{a}$. http://www.ise.ro/wpcontent/uploads/2020/08/Invatarea-la-distanta_Raport-de-cercetare_august2020.pdf

- Cordes, C., \& Miller, E. (2000). Fool's gold: A critical look at computers in childhood. Alliance for Childhood.

- Dell, C., Hobbs, S., \& Miller, K. (2008). Effective online teacher preparation: Lessons learned. Journal of Online Learning and Teaching, 4(4), 602-610.

- Dhawan, S. (2020). Online Learning: A Panacea in the Time of COVID-19 Crisis. Journal of Educational Technology Systems, 49(1), 15-22. https://doi.org/10.1177/0047239520934018

- Di Pietro, G., Biagi, F., Costa, P., Karpiñski, Z., \& Mazza, J. (2020). The likely impact of COVID-19 on education: Reflections based on the existing literature and recent international datasets. Publications Office of the European Union.

- Dong, C., \& Newman, L. (2016). Ready, steady ... pause: integrating ICT into Shanghai preschools. International Journal of Early Years Education, 1-15 https://doi.org/10.1080/09669760.2016.1144048

- Guerriero, S. (Ed.). (2017). Pedagogical Knowledge and the Changing Nature of the Teaching Profession. OECD.

- Dubicka, B., Martin, J., \& Firth, J. (2019). Editorial: Screen Time, Social Media and Developing Brains: A Cause for Good or Corrupting Young Minds? Child and Adolescent Mental Health, 24(3), 203-204.

https://doi.org/10.1111/camh.12346

- Herrington, T., \& Herrington, J. (2006). Authentic learning environments in higher education. Information Sciences Publishing.

- Howard, J., Miles, G.E., \& Ree-Davis, L. (2012). Computer Use Within a Playbased Early Years Curriculum. International Journal of Early Years Education, 20(2), 175-189. https://doi.org/10.1080/09669760.2012.715241

- Hsin, C.T., Li, M.C., \& Tsai, C.C. (2014). The influence of young children's use of technology on their learning: A review. Educational Technology \& Society, 17(4), 85-99.

- Hsu, P. (2016). Examining current beliefs, practices and barriers about technology 
integration: A case study. Tech Trends, 60(1), 30-40. https://doi.org/10.1007/ s11528-015-0014-3

- Downing, J.J., \& Dyment, J.E. (2013). Teacher Educators' Readiness, Preparation, and Perceptions of Preparing Preservice Teachers in a Fully Online Environment: An Exploratory Study. The Teacher Educator, 48(2), 96-109. https://doi.org/10.1080/08878730.2012.760023

- Institutul Na ional de Statistică. (2018). Accesul popula iei la tehnologia informa iilor şi comunica iilor în anul 2018.

https://insse.ro/cms/sites/default/files/field/publicatii/accesul_populatiei_ la_tehnologia_informatiei_si_comunicatiilor_romania_2018.pdf

- Keengwe, J., \& Onchwari, G. (2009). Technology and Early Childhood Education: A Technology Integration Professional Development Model for Practicing Teachers. Early Childhood Education Journal, 37, 209-218. https://doi.org/10.1007/s10643-009-0341-0

- König, J., Jäger-Biela, D.J., \& Glutsch, N. (2020). Adapting to online teaching during COVID-19 school closure: teacher education and teacher competence effects among early career teachers in Germany. European Journal of Teacher Education, 43(4), 608-622. https://doi.org/10.1080/02619768.2020.1809650

- Learning and Teaching Scotland. (2003). Early Learning, Forward Thinking: The Policy Framework for ICT in Early Years. S. Executive.

- Leung, W.M. (2012). An Investigation of the Environment and Teaching Practice of Information and Communication Technologies (ICT) in Pre-Primary Education in Hong Kong. The International Journal of Science in Society, 3(1), 101-116. https://doi.org/10.18848/1836-6236/CGP/v03i01/51313

- Lewis, E., \& Wang, C. (2015). Using an online curriculum design and a cooperative instructional approach to orientate adjunct faculty to the online learning environment. Journal of Continuing Higher Education, 63(2), 109-118. https://doi.org/10.1080/07377363.2015.1042995

- Magen-Nagar, N., \& Firstater, E. (2019). The Obstacles to ICT Implementation in the Kindergarten Environment: Kindergarten Teachers' Beliefs. Journal of Research in Childhood Education, 33(2), 165-179. https://doi.org/10.1080/02568543.2019.1577769

- Magen-Nagar, N., Firstater, E., \& Schwasbky, N. (2013). Characteristics of kindergarten teacher in the information and communication technologies environment: A path analysis. International Journal of Technology in Teaching and Learning, 9(1), 1-17.

- Marshall, C., \& Rossman, G. B. (2011). Designing qualitative research. Sage Publications.

- McMurtrie, B. (2020, March 20). The coronavirus has pushed courses online. Professors are trying hard to keep up. The Chronicle of Higher Education.

- McFarlane, A.E. (2019). Devices and Desires: Competing Visions of a Good 
Education in the Digital Age. British Journal of Educational Technology, 50(3), 1125-1136. https://doi.org/10.1111/bjet.12764

- McQuiggan, C. (2007). The role of faculty development in online teaching's potential to question teaching beliefs and assumptions. Online Journal of Distance Learning Administration, 10(3).

- Mills, S., Yanes, M., \& Casebeer, C. (2009). Perceptions of distance learning among faculty of a college of education. Journal of Online Learning and Teaching, 5(1), 19-28.

- Ministry of Education. (2005). Foundations for Discovery: ICT Framework for Early Childhood Education. Learning Media.

- Ministry of Education and Research. (2020). Strategia privind digitalizarea educa iei din România.

https://www.edu.ro/sites/default/files/Concept\%20SMART-EDU.pdf

- NAEYC. (1996). NAEYC Position Statement: Technology and Young Children. Young Children 5(16), 11-16.

- Nikolopoulou, K., \& Gialamas, V. (2015). ICT and Play in Preschool: Early Childhood Teachers' Beliefs and Confidence. International Journal of Early Years Education, 23(4), 409-425. https://doi.org/10.1080/09669760.2015.1078727

- Paulus, T., Myers, C., Mixer, S., Wyatt, T., Lee, D., \& Lee, J. (2010). For Faculty, by Faculty: A case study of learning to teach online. International Journal of Nursing Education Scholarship, 7(1), 1-17.

https://doi.org/10.2202/1548-923X.1979

- Pederson, S., \& Liu, M. (2003). Teachers' beliefs about issues in the implementation of a student centred learning environment. Educational Technology Research \& Development, 51(2), 57-76.

- Rennie, F., \& Morrison, T. (2013). E-learning and social networking handbook: Resources for higher education. Routledge. https://doi.org/10.4324/9780203120279

- Robinia, K., \& Anderson, M. (2010). Online teaching efficacy of nurse faculty. Journal of Professional Nursing, 26(3), 168-175. https://doi.org/10.1016/j.profnurs.2010.02.006

- Saltmarsh, S., \& Sutherland-Smith, W. (2010). S(t)imulating learning: Pedagogy, subjectivity and teacher education in online environments. London Review of Education, 8(1), 15-24. https://doi.org/10.1080/14748460903557613

- Saude, S., Carioca, V., Siraj-Blatchford, J., Sheridan, S., Genov, K., \& Nuez, R. (2005). KINDERET: Developing Training for Early Childhood Educators in Information and Communications Technology (ICT) in Bulgaria, England, Portugal, Spain and Sweden. International Journal of Early Years Education, 13(3), 265-287.

- Teddlie, C., \& Yu, F. (2007). Mixed Methods Sampling: ATypology with Examples. 
Journal of Mixed Methods Research, 1(1), 77-100. https://doi.org/10.1177/ 2345678906292430

- Teräs, M., Suoranta, J., Teräs, H., \& Curcher, M. (2020). Post-Covid-19 Education and Education Technology 'Solutionism': a Seller's Market. Postdigital Science and Education, 2, 863-878. https://doi.org/10.1007/s42438-020-00164-x

- UNESCO. (2010). Recognizing the potential of ICT in early childhood education-Analytical survey. UNESCO Institute for Information Technologies in Education. https://unesdoc.unesco.org/ark:/48223/pf0000190433

- Wilson, G. (2004). Online interaction impacts on learning: Teaching the teachers to teach online. Australian Journal of Educational Technology, 20(1), 33-48. https://doi.org/10.14742/ajet.1366

- Wray, M., Lowenthal, P., Bates, B., \& Stevens, E. (2008). Investigating perceptions of teaching online and F2F. Academic Exchange Quarterly, 12(4), 243-248.

- Yelland, N., Lee, L., O'Rourke, M., \& Harrison, C. (2008). Rethinking Learning in Early Childhood Education. Open University Press.

The online version of this article can be found at: http://revped.ise.ro/category/2020-en/

\section{(c) BY-NC-SA}

This work is licensed under the Creative Commons Attribution-NonCommercial-ShareAlike 4.0 International License.

To view a copy of this license, visit http://creativecommons.org/licenses/by-nc-sa/4.0/ or send a letter to Creative Commons, PO Box 1866, Mountain View, CA 94042, USA.
Versiunea online a acestui articol poate fi găsită la: http://revped.ise.ro/category/2020-ro/

\section{$( C C ) \longdiv { B r - N C - 3 A }$}

Această lucrare este licen iată sub Creative Commons Attribution-NonCommercial-ShareAlike 4.0 International License.

Pentru a vedea o copie a acestei licen e, vizita $i$ http://creativecommons.org/licenses/by-nc-sa/4.0/ sau trimite i o scrisoare către Creative Commons, PO Box 1866, Mountain View, CA 94042, SUA. 